\title{
Creation and 'Actualism': The Dialectical Dimension of Philosophical Theology
}

\author{
DAVID B. BURRELL, C.S.C.
}

"Philosophical theology" is a descriptor coined in the 1960s by the contributors to a group endeavor, entitled New Essays in Philosophical Theology, which meant to bring the tools of analytic philosophy to bear on topics long recognized to be theological in character, yet with considerable philosophical resonance. It was subsequently adopted by those who wished to do just that: bring their philosophical expertise to issues theological, without being thereby constrained to consider the traditional "preambles to faith" that had become the stock in trade of a discipline called "natural theology": the existence of God, the possibility of divine revelation, and the capacity to discourse at all about such transcendent objects.

The model operative here had been one in which reason was invoked to establish the truth of certain claims that were deemed to be presupposed to a reasonable assent of faith. And since reason was supposed to function with evidence available to all, its deliverances were considered "natural," while those of faith were "supernatural," indicating that something more than evidence was at work in the assent of faith. Whatever the preoccupations of the contributors to the New Essays symposium, others of us who have adopted that title for our work wanted not only to expand the range of theological topics available for philosophical inquiry, but also to intimate a new model 
for the relation of reason and faith. Rather than a stepwise pattern that suggested a foundational approach to matters of faith, we preferred to direct our attention to the tradition of Christian theology, as one in which the community had availed itself of reason from the outset in the elaboration of its faith and its own self-understanding. By attending to the explicitly philosophical contributions to that endeavor, those who style themselves "philosophical theologians" have tried to bring some distinctive critical tools to assessing the larger endeavor of Christian theology and especially to adjudicating its claims to truth. Moreover, there are convincing hermeneutic arguments that the medievals never considered the discussions involving the "preambles to faith" to be foundational in character, but rather to be a retrospective inquiry into the presuppositions required for any consideration of the truth of the articles of faith. ${ }^{1}$

It is the assessing and adjudicating role of philosophy, however, that deserves a fresh look today, in the light of recent reflections on the role of tradition in guiding inquiry, and specifically out of respect for the primarily theological focus of the work in this field. For if the mode is expressly philosophical, the issues are theological, and theology operates far more historically than many philosophers are accustomed to proceed. The notions that proved crucial to the early doctrinal formulations of Nicaea and Chalcedon, for example, were themselves forged over three centuries of debate, in which their meaning and intent were shaped to the specific role they were to play in that discussion. Apprising oneself of this conceptual development means entering into the theological tradition itself, at least enough to follow the reasoning presented for modifying the philosophical terms in play, so that the discourse will be assessed in its own terms rather than presuming it to be employing a putatively neutral idiom. Absent such efforts, we cannot presume we are discussing the theological issues we set out to examine, but only a procrustean version of them that we take to be "coherent" within prevailing horizons. But one of the salient contributions of theological questions to philosophy has ever been to challenge the adequacy of current horizons. It is in the interest of good philosophy as well as accurate theology to

1. Guy de Broglie, "Le vrai sens de preambula fidei," Gregorianum 34 (1953): 345388. 
show how the criteria of assessment are inherently dialectical in a merged discipline like "philosophical theology." What follows intends to illustrate that contention with respect to an avowal shared by Jews, Christians, and Muslims alike: that the universe comes forth from God freely and deliberately.

In the medieval discussion, the operative counterpoint was the scheme of necessary emanation from the One, in which all-that-is flows from that source in much the same way as many premises may be deduced from a single axiom. What the Bible and the Qur'an were presumed to say, however, was that the creator who freely bestowed those revelations also brought forth the universe as an utterly free gift: neither responding to any need in the creator nor presuming any stuff with which to work. The resulting challenge to philosophy is to find a conceptuality that will articulate how all-that-is is freely originated and exists in dependence on the One. This is indeed an exercise in theology, since those who don't accept this story of origination could hardly be bothered. Yet it is a philosophical exercise as well, since the issues involved are inescapably metaphysical: there could be no witnesses of such an origination. I shall contrast two ways of articulating this situation, arguing that one of them is more compatible with the original assertion of the revelatory sources, and for that reason ought to recommend to us the ontology employed. In other words, rather than simply assess the adequacy of a revelatory statement according to our philosophical horizons, I want to show how the faith horizon can also exercise a normative role in leading believers to prefer one ontology to another.

It is commonly presumed that the alternative to a necessary emanation of the universe from its source is a picture of the creator selecting which universe to create. This picture coheres with our commonly held presumption that choosing is the paradigm for the exercise of freedom. It seems that if there were no choice in the matter, the creator would be constrained, and this universe would be the only universe possible, given the creator it has. I shall argue against the picture, as well as the metaphysics that it suggests: one that privileges possibility over actuality. I will do so from the perspective of affirming the free creation of the universe from the One. Once we are alerted to the fact that this universe is indeed a free gift, rather than the given context of all that we can say or do, we will be even more concerned than Aristotle was to make of individual existing things our paradigm 
for what-is. The utter freedom of creation not only denies any need on the part of the creator, but also any prior constraints on the part of the world-to-be-created. There is no possibility preceding God's free origination, except by reference to the power of God. ${ }^{2}$ So there are no "possible worlds" from which the creator selects this one, as though God's action in creating were primarily a matter of will and indeed of choice.

It is true that many who so construe creation do not think of the presence of such "worlds" as a prior constraint on God, since the worlds are rather conceived as products of the divine mind, one of which the divine will "actualizes." Indeed, nothing would seem to enhance the scope of the divine intellect so much as to think of God knowing in detail all possible configurations of all possible states of affairs, necessary and contingent, and selecting this one! Nothing, that is, except the thought that some of these states of affairs will involve actions of free individuals, so that knowing their outcome would presume a determinacy unavailable before that person existed and performed the action. Actiones sunt suppositorum, as the medieval axiom had it: actions result from existing individuals. To put it another way: possible configurations may give us a scenario, but not a history. And we all know that scenarios are parasitic on histories. The anticipated responses of standard scenarios are distilled from what we know of behavior in the past. Possibility follows actuality when one speaks of "worlds," even if in a constituted world, potentiality precedes actuality. Yet it remains true, doesn't it, that what-is could have been otherwise? Isn't that what "contingency" comes to? In a universe that is merely given, this would be the operative sense of "contingency": understanding that some states of affairs in the world could indeed have happened otherwise, while others could not. Indeed, distinguishing invariant from variable features of the world is part of our basic orientation. But when the universe is a free gift, there is another level of contingency beyond that which presupposes the actual configurations and then recognizes that many of them are in fact variable. It is rather the level that acknowledges that all this might not be at all. Such a recognition represents another level of contingency because even what happens by "natural necessity"

2. Thomas Aquinas Summa theologiae 1.46 .1 ad 1. 
may yet be said to be contingent in this sense. In fact, "no creature can be said to be absolutely necessary, for it is necessary only on the supposition that the divine will has unchangeably decreed its preservation."3 For "just as before things existed on their own it was in the creator's power for them to exist, so now that they do exist on their own it is in the creator's power for them not to exist." 4

So it seems that the presence of a free creator adds a dimension to ordinary discourse about possibility and necessity, emphasizing that they are modalities of existing, which is the free gift of the creator. "Just as bringing things into existence depends on God's will, so also preserving them in existence. For [God] preserves them in existence only by perpetually giving existence to them, and were he therefore to withdraw his activity from them all things ... would fall back into nothingness." 5 This statement of Aquinas, the sense of which he attributes to Augustine, shows how crucial it is whether one treats the divine origination as a mere presupposition or as a continuing presence. If the originating activity is but presupposed, the universe can be considered, like that of the Greeks, a given. If that activity is indeed pervasive, however, "actuality" takes on a new valence. One may indeed speak about how things might have been, but as possibilities. They remain relative to the power of God to create them, and so say little more than that things could have been otherwise than the way in which they are. How much otherwise is a disputed question, as recent discussion surrounding the "universal constants" attests.

What appears from this perspective to be a fruitless enterprise is to extrapolate randomly from the world that we know into other "possible worlds." The inverse of the complaints of empirical philosophers regarding "God-talk" recurs in this context: such flights of fancy presume that too many of the implications from the actual world to remain as we alter one feature after another of the world we think we know. How little we really know of the intricacies of this world is dramatized by the "universal constants" discussion. In fact, this is the only world we know; we remain quite ignorant of those features which make it into a unified, functioning whole, in short, a world. Aquinas called this pervasive and transcendental feature the "order of

3. Thomas Aquinas Quaestiones disputatae de potentia 3.17 ad 3.

4. Thomas Aquinas Summa theol. 1.9.2.

5. Thomas Aquinas Summa theol. 1.9.2. 
the universe as a whole [bonum ordinis universi]" and considered it to be the "primary intent" of the creator. ${ }^{6}$ Since the various sciences have only begun to explore the synergies proper to ecological interaction, we rightly confess a large degree of unknowing in regard to this order, yet we can perceive enough to marvel at its intricacies. Once again, the positive valence of actuality strikes us forcibly. Even while we know that this world "could be otherwise," we remain unable to identify those features which make it into the world that it is or to tell why they do so. We are reminded of the rhetoric of al-Ghazali and Maimonides in the face of an ostensibly philosophically superior scheme of "necessary emanation": what one really ought to marvel at is the conjuncture of things that we cannot explain yet which make this world what it is, for these patterns-unpredictable by the sciences available to them-display the wisdom of the creator. ${ }^{\text {? }}$

Indeed, this accent on the world in which we live as the world that is the free gift of the creator (and so the only bona fide "world" that we know) calls into question the utility of modal logic and of "possible world" semantics more generally to articulate the relation of creator to creation. These "worlds" remind one of alternative emanation schemes, replacing "necessary" with "possible," yet retaining the sense that God is "in" each of them. In fact, the "distinction" of creator from creation is what is at stake-what Ibn Sina had identified as the bifurcation in being between necessary and possible. ${ }^{8}$ This represented the first attempt of an Islamic philosopher to factor in the difference that an originated universe could make to one's metaphysics. The device that he employed was to distinguish essence from existence in such wise that everything other than the First received its existence from that First, whose uniqueness was assured by the fact that its essence [dhat] was identified with existing. ${ }^{9}$ So

6. Thomas Aquinas Summa theol. 1.15.2.

7. Al-Ghazâlî, Al-maqsâd al-asnâ fî sharh ma'ânî asma' Allah al-husnâ, 'al-'adl', translated as Al-Ghazâlî on the Ninety-nine Beautiful Names of God (Cambridge: Islamic Text Society, 1992); Moses Maimonides Guide of the Perplexed 2.19, 2.24, 3.13.

8. See Burrell, "Essence and Existence: Avicenna and Greek Philosophy," MIDEO 17 (1986): 3-66. For the sense of 'distinction' here, see Robert Sokolowski, The God of Faith and Reason (Notre Dame, Ind.: University of Notre Dame Press, 1982).

9. Fazlur Rahman, "Essence and Existence in Avicenna," in Mediaeval and Renaissance Studies [London] 4 (1958): 1-16. 
while Avicenna regarded "possibles" as presupposed to the activity of emanation, what distinguished the necessary being from all that might be (i.e., what is merely possible in itself), as well as from what exists (i.e., what is possible in itself yet necessary from another), is also what makes it unique. While it lacks existence as something "coming to it," it nevertheless enjoys existing as what "belongs to it"-the etymological root of 'dhat', the term Alfarabi had already coined for God's unique essence. 10

Ibn Sina's account of God's necessity and the world's contingency was bedeviled by two interrelated factors. First, there was his way of characterizing existing as "what comes to something" and hence an "accident" (since the Arabic expression for 'accident' bears the same relation to the root verb as our term does to the Latin verb 'accidere', 'to come to'). There was, second, his identification of existing with the "necessity" that obtains among existents by virtue of their emanation from the One. These are connected in that the vague characterization of existing as "what comes to something" makes it into an attribute, which attribute is then identified with a place in a formal scheme. So what we recognize as contingency in existing things, their "precarious" status as existents, is translated into a derivative form of necessity, namely their place in a necessary scheme. What distinguishes all such items from the One that is necessary is simply that each of them is what it is already (as it were) as a merely possible, whereas God alone is such that it could not not be. Now the force of existing as "coming to something" emerges: the item in question is already constituted "before" existing, so that the characterization is relatively apposite, despite the self-referential problems which obviously arise when one so defines existing.

Now we may see the connection between Avicenna's scheme and "possible worlds" treatments of these issues. "Possibles" in both cases are taken to be identifiable prior to their existing (or being actualized) -indeed, to be exhaustively so. (There are subtle differences whether one is referring to "objects" or to "states of affairs," but these are quite compatible with the similarities we shall develop here.) So on both counts, "actualizing" may be thought of as the emerging of something

10. See Burrell, Knowing the Unknowable God (Notre Dame, Ind.: University of Notre Dame Press, 1986), p. 16 (Farabi), 39-40 (Ibn Sina). 
into full-blown reality, or alternatively, as existence (or actualization) "coming to" it, where the it is already given. So existence is, in the current jargon, "an on/off property: either you're there or you're not." 11 It should be immediately evident how such a notion jars with the assertion shared by Jews, Christians, and Muslims of a creator who brings all-that-is into being. The picture operative here is more like a demiurge who, instead of fashioning out of pre-existent material, selects among a plethora of "possibles." With the Jewish, Christian, or Muslim God, however, the "possibles" could indeed be the product of the divine intellect, so nothing would be postulated as extraneous to the creator (except perhaps those "necessary truths" that would have to attend all possible configurations). So the mere assertion of a creator who is not a demiurge does not decide the matter. What does come nearer to deciding it is the conception of creation with which one is operating. Since this is usually quite implicit, the alternatives deserve to be developed.

If the creator is the source of all-that-is, and hence of the perfections of things, the creator will be the source not merely of their "existence" (in the "on/off" sense), but of all that emanates from their existing. Operations above all are the sign of something's existing, so it follows that the initial and grounding perfection is existence itself. If that be the case, this utterly "non-qualitative property" of existence will be the "proper effect of the first and most universal cause, which is God." 12 From that divine activity will flow all that comes to be from such creatures. Far from being an initial "floor," an "on/off property," what the act of creation bestows, in creating this world, is what makes it to be and to be a world: the existential order that is the only matrix within which action occurs. Since this bestowal is free (by the shared belief of Jews, Christians, and Muslims), we are also led to believe that such a One could have created otherwise, as well as not having created at all. Nothing whatsoever licenses us to picture the freedom to have

11. Christopher Hughes, On a Complex Theory of a Simple God: An Investigation in Aquinas' Philosophical Theology (Ithaca and London: Cornell University Press, 1989), p. 27.

12. Thomas Aquinas Summa theol. 1.45.5. For the notion of "non-qualitative property," see R. M. Adams, "Theories of Actuality," Nous 8 (1974): 211-231, reprinted in The Possible and the Actual, ed. Michael Loux (Ithaca, N.Y.: Cornell University Press, 1979), pp. 190-209. 
created otherwise as a selection among determinate "possibles." In fact, much leads us in another direction: the inscrutability of the divine wisdom, recently reinforced by astrophysical reflection on the "universal constants," might make us wonder just how different this universe could be, in its very structure, and remain a universe.

However we may decide that (undecidable?) question, the presence of human freedom would follow as a perfection utterly consonant with the existential order of a universe conceived as the gift of a free creator. Such a One would be empowered to create existents whose operations were natural as well as others whose operations were also intentional. In fact, the natures of intentional beings would be to be free. Just as the creator who is the cause of being "imparts to creatures also the dignity of causing,"13 so also that same creator makes some such creatures free agents. That need not inhibit the certitude of providence, for "to be necessary or contingent are corollaries to being as such." 14 This last assertion is the crucial challenge to a metaphysics able to articulate the scope of a creator of all-that-is, and to do so in a way that also articulates "the distinction" as well. Such a One is not "faced with" necessities any more than subverted by contingencies, for this One need not "negotiate" the world it creates. What is also needed is a manner of understanding this relationship that avoids the spatial images connected with a "transcendence-immanence" scheme. It would only be accurate to say that this One is "beyond" necessitycontingency if we were also prepared to say that it is so because this is the very One that sustains all-that-is in being, whether its mode of being is necessary or contingent. So what is required, as James Ross has been reminding us, is a way to articulate a "cause of being":

omnipotence is FORMALLY not the power to make states of affairs obtain or to actualize the possible. It is the power to cause being ex nihilo... . Its domain is realized with its exercise. What is possible ad extra is the result of what God does. God's power has no exemplar objects, only a perimeter (that is, finite being) plus a limit (that of internal consistency, compatibility with divine being). God creates the kinds, the natures of things, along with the things. And [God] settles for what-might-havebeen insofar as it is a consequence of what exists; for example, you might have been wealthier. Thus, there is no mere possibility with content (for

13. Thomas Aquinas Summa theol. 1.22.3.

14. Thomas Aquinas Summa theol. 1.22.4 ad 3. 
example, "there might have been only Marticils, silicon-based percipients, native to Mars"); there are only descriptions, actual and potential, that might, for all we know so far, have been satisfied. They do not, however, "pick out" any definite content that, if actual, would satisfy them. All content ad extra is caused by God. In sum, God creates the possibility, the impossibility, and counterfactuality that has content (real situations) involving being other than God. ${ }^{15}$

Those who must begin with "possibilities" rather than with the act of creation would locate what Ross calls "definite content" in the "divine ideas," some of which the creator "actualizes" in creating this world. They often appeal to Aquinas's treatment of "divine ideas" to underscore their point. ${ }^{16}$ Yet their appeal tends to miss the deft way in which Aquinas altered this neoplatonic legacy to subserve his accentuating God's creative knowing as practical. It is only in the measure that God is creator that there is need at all for ideas, since the divine intellect as such has no need of "being informed by a plurality of species" by which it knows. ${ }^{17}$ Indeed, divine simpleness would be violated were that required. Yet once we speak of God freely creating, then ideas become a convenient way for us to articulate the fact that God creates deliberately, and the idea serves as "that which is known, [as] the form of a house in the mind of the architect is something understood by him, to the likeness of which he produces the form of a house in the matter." 18 It should be clear that Aquinas is employing an analogy, and one which underscores the practical dimension of the knowing associated with creating. It is in that context that he then distinguishes two senses of 'idea', both of which he acknowledges to be inherited from Plato: "as a principle of the production of things it may be called an exemplar, and belongs to practical knowledge; as a

15. See James Ross, "God, Creator of Kinds and Possibilities: Requiescant universalia ante res," in Rationality, Religious Belief, and Moral Commitment, ed. Robert Audi and William Wainwright (Ithaca, N.Y.: Cornell University Press, 1986), pp. 315-334, especially p. 318; and Ross, "The Crash of Modal Metaphysics," Review of Metaphysics 43 (1989): 251-279.

16. Thomas Aquinas Summa theol. 1.15; Quaestiones disputatae de veritate 3.

17. See the discussion between William Alston, "Does God have Beliefs," Religious Studies 22 (1986): 287-306, and William Hasker, "Yes, God has Beliefs," 24 (1988): 385-394. Compare John Farthing, "The Problem of Divine Exemplarity in St. Thomas," Thomist 49 (1985): 183-222.

18. Thomas Aquinas Summa theol. 1.15.2. 
principle of knowing, it is properly called a ratio, and can belong also to speculative knowledge." 19 This ratio "is related to all the things God knows, even though they never come into existence; and to all the things [God] knows in the rationes proper to each, and as known by [God] in a speculative way."

This distinction Aquinas had already made in the previous question, in asking "whether God has knowledge of non-existent things"? 20 He distinguished there between two modes of knowing by their objects: of those things which were, are or will be, "all these God is said to know by knowledge of vision," while of those "which can be produced by God or by creatures, yet are not, were not, and never will be, . . . God is said to have . . . knowledge of simple understanding." The use of 'vision' to name God's creating (or practical) knowledge reflects the fact that "in ourselves things seen have a separate existence outside the one who sees." Such items, then, are present to God as items that God creates; the "others" need not be so construed: in fact, what knowledge of simple understanding amounts to is God's knowing "the divine essence... as it can be participated in some degree of likeness by creatures." 21 But in the case of knowledge of vision, "God, in knowing [the divine] essence as imitable in this particular way by this particular creature, knows [the divine] essence as the nature and idea proper to that creature." This knowing, which is practical, terminates in a particular creature with its "proper nature," while the first terminates only in a "proper ratio," indicating how the divine essence could indeed be participated. That is why Aquinas calls it "knowledge of simple understanding" and why he notes that it is speculative in character. It should be clear, then, that Aquinas is not an "exemplarist," in the sense identified by Ross, according to which God first knows in a determinate way all the items God could create, and then chooses among them certain ones to "actualize." Aquinas reserves the term 'exemplar' to the exercise of divine practical knowing and so to those things which have existed, do or will exist. Beyond terminology, the critical point is that the creator need not be a platonist to create in a deliberate fashion. Aquinas's treatment of "divine ideas" cannot be adduced as evidence for such

19. Thomas Aquinas Summa theol. 1.15.3.

20. Thomas Aquinas Summa theol. 1.14.9.

21. Thomas Aquinas Summa theol. 1.15.2. 
a contention; indeed it testifies to the contrary. But how may we formulate that contrary more precisely?

By noting how Aquinas transformed Avicenna's observations about "existing coming to" things into an ontology that privileges existing over essence, as act of a potency. If existing is not the merest fact about things, but rather the source of all their subsequent perfections, then it will follow that existing is the "proper effect of the first and most universal cause, which is God."22 Whatever else there is-natures, powers, inclinations, habits, actions-is dependent upon those individuals' existing which embody them. It should be clear that 'existing' here means just that. It is not the denatured 'existing in' found in statements like "every object has existence in each world in which it exists." 23 For such statements reduce 'existing' to a "property ... essential to each object, and necessarily so," which property comes down to an object's belonging to a "possible world," so that the very point of Avicenna's original distinction is subverted, and one is constrained to substitute a new word 'actuality' for 'existence' as we normally use it. The alteration is far more than terminological, as we have seen; it brings with it an ontology that privileges possibility over actuality, and thereby makes it very difficult to understand what 'actuality' means, other than to identify the world that happens to be from among all those which could be. ('Contingency' is given a strong sense-this world just 'happens to be'-while the very being of the world is given short shrift.)

Alternatively, if what-exists is all we have, and what-is-possible is parasitic upon that, then another dimension is added to "contingency." It is not merely that things might have been otherwise, or that another "world" might have been "actualized," but that those things which exist might not have existed at all. That there might not have been anything at all was unthinkable to the Greeks, and equally so, it seems, to purveyors of "possible worlds," for whom 'exists' as we normally use it is a special case of 'exists in' (as in 'exists in a possible world'). One can always suppose another "possible world." Yet this difference is no doubt illustrative, for as Sokolowski insists, the capacity to think "contingency" in this more radical sense is clearly

22. Thomas Aquinas Summa theol. 1.45.5.

23. These citations are from Alvin Plantinga, "Actualism and Possible Worlds," in The Possible and the Actual, ed. Loux, p. 261. 
a function of the affirmation of a free creation. "The world is now understood as not having had to be, [which amounts to] the denial that God . . . is part of or dependent on the world, . . is glimpsed on the margin of reason, . . . at the intersection of reason and faith." 24 With that "distinction" comes the corollary that God, as free creator, is the cause of all-that-is, and of the modalities that follow upon being. What we formulate as "necessities" are not thereby made arbitrary; they depend on the divine nature rather than on the divine will, as what God understands must be the case if the divine essence is to be imitated by such a created nature. In that respect, necessities would seem to function more like rules of inference or like the constraints of matter, purpose, and appropriate agency in building something, than like constituent parts of created things. Such formal features differ from other constituents in that things are not made of them.

Moreover, if God's "necessity" is defined by what makes such a creator unique, namely that God's very essence is to-exist, then the primacy of existing will be confirmed in the clearest way possible. The One from which all-that-is comes to be exists in and by itself. What it bestows in creating will be a share in that perfection of existing, so that the very existence of the creature will consist in "a relation to the creator as the origin of its existence." 25 Even if the formulation of necessity as "being true, or obtaining in, all possible worlds" were an adequate account of the modal notion (which Ross challenges), ${ }^{26}$ it would hardly succeed in formulating what it is about God's being necessary that further identifies such a One as the creator, indeed, as the free creator of all-that-is. Perhaps that is more than one ought to ask of such an account, but a characterization of God that required a separate premise to assure that such a One is the origin of allthat-is would hardly be adequate to articulate the faith of those who believe in free creation. Some other metaphysical scheme is clearly required. It must be able to characterize a One that need not create and from which all that is emanates. Moreover, since this world is the only world we know, and is deemed to be the one that God freely creates, underscoring the primacy of existing as what individuates by

24. Sokolowski, God of Faith and Reason, pp. 34, 37, 39.

25. Thomas Aquinas Summa theol. 1.45.3.

26. Ross, "The Crash of Modal Metaphysics," p. 270. 
granting a participation in the divine act of existing offers itself as a metaphysical corollary of the original faith.

Furthermore, identifying the existence of the creature as "a relation to the creator," and hence as "what is more intimately and profoundly interior to things than anything else," 27 including what makes each thing to be what it is (its essence), goes a long way to overcoming the imaginative bifurcation of transcendence-immanence. By reminding us that the "proper effect" of the free creator in things will by definition transcend the causal order of creatures, we are also brought to realize that this same effect will define what is most "intimately and profoundly" interior to created things. The distinction of existence from essence becomes the axial conceptual tool for articulating "the distinction" of God from the world by formulating the relation of creature to creator. Moreover, the conceptual obscurity of the key notion of existing also follows from the scheme itself, for were the "relation to the creator" in which created existing consists to be accessible in terms proper to the created universe itself, that is, if it were identifiable as a feature of the world, then its transcendence would be lost and "the distinction" elided. We see that the essence-existing distinction, as formulated by Aquinas so as to extend Aristotle's axial categories of potency-act, belongs to the same "logical neighborhood" as "the distinction" itself. Avicenna's formulation of existing as something "coming to the essence" would be more accessible to reason alone, however incoherent it may be seen to be. Aquinas's distinction seems to be as much "on the margin of reason" and hence "at the intersection of reason and faith," as is "the distinction" of God from the world. 28

My reliance on Aquinas throughout is strategic rather than doctrinal. If the prime concern of philosophical theology is to elaborate the essentials of a faith-tradition, with special attention to the so-called

27. Thomas Aquinas Summa theol. 1.8.1.

28. This remark takes a position on a controverted question among students of Aquinas. See the debate between John Wippel and Joseph Owens in Wippel, "Aquinas' Route to the Real Distinction: A note on De ente et essentia, ch. 4," Thomist 43 (1979): 279-295, with Owens's response, "Stages and Distinction in De ente: A Rejoinder," Thomist 45 (1981): 99-123; followed by Wippel's reply in his Metaphysical Themes in Thomas Aquinas (Washington, D.C.: Catholic University of America Press, 1984), pp. 120-132. 
preambula fidei, then it could be argued that the most critical of these is "the distinction" of God from the world. Everything turns on the character of the divinity that one wishes to set forth as existing, as revealing itself, and as guiding the terrestrial course of events. Much of that character is decided in attempting to articulate that One as the free creator of all-that-is. So it was that Aquinas, confronted with an Islamic philosophical tradition that had compromised the Qur'an's clear assertion of a free creation, yet emboldened by the arguments of Moses Maimonides to the effect that no philosopher had been able to demonstrate the "eternity of the universe," managed to find a clear metaphysical way of characterizing such a divinity. Beginning with a description of this One compatible with all three traditions-" "the beginning and end of all things and of reasoning creatures especially" 29 - he was able to transform Ibn Sina's version of "the distinction" into the more coherent formula of existing as the act to which any essence was in potency. He thereby established "the First" as that One which had no need to create, being its own existence. The One whose very nature is to-exist will, by that fact alone, merit the transcendence that Plotinus could claim for his "One" only by locating it "beyond being," since everything-that-is exists in such a way as to be distinct from its existing. Moreover, by identifying the divine essence with its existing, Aquinas succeeded both in distinguishing God's existing from that of everything-that-is and in relating the creator to all creatures, as participants in that singular act of existing which is God.

One question alone seemed to be left hanging for Aquinas, as he negotiated a path for faith through the philosophical universe of his day. The One of Plotinus (and of Avicenna) was not so much moved by need to emanate the universe, as by an inner necessity of sharing the superabundance of its being: bonum diffusivum sui est ("good is diffusive of itself"). If that were so, then the divine freedom in creation would be entirely "natural" to the One. I say that this question seems to have been left hanging for Aquinas. While the identification of divine essence with existing would clearly rule out need, it would not so clearly circumvent this sort of "natural overflow" of goodness. 30

29. Thomas Aquinas Summa theol. 1.2 prologus.

30. Norman Kretzmann's articles to this effect corroborate the fact that this remains an issue for Aquinas. See Kretzmann, "Goodness, Knowledge, and Inde- 
Aquinas says so himself when he indicates why "knowledge of the divine persons [in the Trinity] is 'necessary' for us [to have] the right idea of creation: the fact of saying that God made all things by His Word excludes the error of those who say that God produced things by necessity. [And] when we say that in [God] there is a procession of love, we show that God produced creatures not because He needed them, nor because of any other extrinsic reason, but on account of the love of His own goodness." 31 We can use Aquinas's response to address our immediate question by noting that the ordered processions of Word (Son) and of Love (Holy Spirit) in divinis certainly suffices to meet the "spontaneous overflow of goodness" consideration of Plotinus, and it does so in a manner utterly faithful to the pagan philosopher's (as well as Jews' and Muslims') strictures on divine unity. Showing that to be the case would require an excursion into formally Christian theology inappropriate here. It should suffice to note that Aquinas so constructed his treatment of God's triunity as to be compatible with the twin concerns of faith and of metaphysics: the uncompromising unity of divinity as well as the utter impossibility of concluding to the presence of such processions in God. The first concern is one of philosophical theology, critical to articulating "the distinction" of God from the world; the second is a matter of faith, identifying the domain proper to God's self-revelation.

Any metaphysical scheme may, and probably will, leave some questions hanging to which the revelatory tradition alone will be able to give adequate response. So also will there continue to be debate regarding which scheme better articulates that tradition. But one thing should be beyond discussion: no tradition of faith can avoid being elaborated from within by metaphysical notions, which alone will be able to capture the transcendent relation of divinity to all-thatis. The criteria of adequacy will always be mutual, as faith seeks understanding, and understanding allows itself to be amplified by revelation. There is no procrustean set of "cutters" that are themselves structured so as to cut either side down to size. Philosophical theology must needs

terminacy in the Philosophy of Thomas Aquinas," Journal of Philosophy 80 (1983): 631-649, and "A General Problem of Creation: Why Would God Create Anything at All?" in Being and Goodness, ed. Scott MacDonald (Ithaca, N.Y.: Cornell University Press, 1984), pp. 208-228.

31. Thomas Aquinas Summa theol. 1.32 .1 ad 3. 
develop those sorts of skills which foster a dialectical confrontation of criteria from both sides, as each side of the classical faith-reason divide employs intelligence at the service of understanding.

University of Notre Dame 